\title{
Sustainable agriculture trough regional solidary in global markets
}

\author{
Wellbrock Wanja ${ }^{1 *}$, Daniela Ludin ${ }^{2}$, Ludwig Lisa ${ }^{3}{ }^{3}$, Muhlfeld, Kristina ${ }^{4}$, Wolfgang Gerstlberger ${ }^{5}$ \\ 1, 2, 3,4 Heilbronn University of Applied Sciences, Schwabisch Hall, Heilbronn, Kunzelsau \\ ${ }^{5}$ Tallinn University of Technology, Tallinn, Estonia
}

\author{
Keywords \\ Community supported \\ Agriculture \\ Sustainability \\ Regionality \\ Economic efficiency
}

\begin{abstract}
This paper examines whether Community Supported Agriculture (CSA) is a solution to the dilemma of farmers having to operate economically and sustainably simultaneously. This includes an analysis of changing ecological and economic conditions as well as motives for founding or joining a CSA. The core is an expert interview and a survey of members, which identifies problems in the realization of a CSA and provides possible solutions.
\end{abstract}

Received: 6 September 2019

Accepted: 7 November 2019

Published: 12 February 2020

\section{INTRODUCTION}

\section{A. Problem Definition}

The oil crises of the 1970s highlighted the finiteness of fossil resources and drew attention to the changed environmental conditions caused by their combustion [1]. A sustainability movement emerged with the aim of reconciling economic interests, such as wealth growth, with social and environmental goals. Especially in agriculture, difficult conditions are evident due to changed framework conditions [2], which is why the sustainability movement is also spreading to the agricultural sector [3]. Additional demands from politics and society for higher sustainability standards represent an increasing challenge, especially for small farmers. The demand for sustainability secures the future, but demands high investments [4], which are difficult to make due to the poor economic and financial situation. The reasons for this are the monetary misallocation of production costs, the price of agricultural products and growing competitive pressure [5].

\section{B. Objectives}

Alternative Food Networks (AFNs) address the dilemma of farmers having to act economically and sustainably at the same time. The biggest alternative to industrial agriculture is CSA. The CSA is an alliance of agricultural enterprises with private households to form an economic community [6]. This paper examines whether the concept of the CSA is a solution to the dilemma. In addition to the analysis of existing literature, the statements were compared and supplemented using the CSA in southern Germany. The challenges faced by farmers and the economic viability of the CSA concept were analyzed. Members were asked about their value changes through membership and their statements were compared with the results of previous studies. This includes the consumer behavior, as well as the social commitment of the members before and after their accession to the CSA. This determines whether this concept has a positive impact on the sustainable development of a society. Based on the results of the study, the CSA interviewed was

\footnotetext{
${ }^{*}$ Corresponding author: Wellbrock Wanja

†email: wanja.wellbrock@hs-heilbronn.de
} 
given a recommendation for the recruitment of new members in order to ensure long-term financial security.

\section{Structure of the Work}

After the introduction in Chapter 1, the research design of the work is described in Chapter 2. This comprises the research questions within the scientific fields of sustainability economics, agricultural economics and public welfare economics. In addition, the methodological approach is described. Chapter 3 contains the theoretical examination of the scientific fields, which are supplemented by the empirical results in Chapter 4. The results are summarized and discussed in Chapter 5. This also includes an outlook and a recommendation for the surveyed CSA.

\section{Research Design}

TABLE 1

RESEARCH QUESTIONS

\begin{tabular}{|c|c|c|c|c|}
\hline Scientific Field & No. & Research Questions & Method & Chapters \\
\hline \multirow[t]{5}{*}{ Sustainability economics } & 1 & What are current global environmental problems? & Literature analysis & 3 \\
\hline & 2 & $\begin{array}{l}\text { How does the sustainability movement influence the agricultural } \\
\text { sector? }\end{array}$ & Literature analysis & 3 \\
\hline & 3 & What does sustainability mean? & Literature analysis & $3 / 4$ \\
\hline & 4 & Which factors make sustainable development more difficult? & Questionnaire & 4 \\
\hline & 5 & Can agricultural concepts promote sustainable behavior? & Literature analysis & $3 / 4$ \\
\hline \multirow[t]{5}{*}{ Agricultural economics } & 6 & $\begin{array}{l}\text { What are the framework conditions that characterize the agricul- } \\
\text { tural sector? }\end{array}$ & Literatur analysis & 3 \\
\hline & 7 & What are the consequences of climate change for agriculture? & Literature analysis/ Interview & 3 \\
\hline & 8 & What is the financial situation of farmers? & Literature analysis & 3 \\
\hline & 9 & Is there any financial state support for farmers? & Literature analysis/ Interview & 3 \\
\hline & 10 & What kind of competition exists in agriculture? & Interview & $3 / 4$ \\
\hline \multirow[t]{4}{*}{ Public welfare economics } & 11 & What is a CSA? & Literature analysis & 4 \\
\hline & 12 & What are the motives of farmers and members of a CSA? & Questionnaire & 3 \\
\hline & 13 & What are the challenges facing the CSA? & Questionnaire Interview & 4 \\
\hline & 14 & $\begin{array}{l}\text { How does the CSA affect the consumptions behavior of members in } \\
\text { a CSA? }\end{array}$ & Literatur analyses & 4 \\
\hline
\end{tabular}

\section{E. Methodical Approach}

Within the scope of this topic, a literature analysis on the scientific fields of sustainability, agricultural economics and public welfare was carried out with the help of international online databases and library catalogues [7, 8, 9]. When recording the generally prevailing theory from standard works, attention was paid to the seriousness of the sources; the journals used were checked using peer-reviewed methods [10].

The method of questioning was used to systematically analyze social reality and compare the results with those of the literature [11]. The establishment of CSAs was also the result of changes in social behavior [12]. In order to be able to record and analyze this behavior as empirically as possible, the survey method was used [11]. The information collected includes the experiences of the farmer and founder of the surveyed CSA as well as those of the members. The primary data was collected orally through an interview with the founder and in writing in the form of a questionnaire addressed to the members [10].

A survey form was designed for the survey in order to avoid interference between the members and to guarantee the anonymity of the answers cc. The survey was conducted between 26th November 2018 and 01st December 2018. In addition to six closed questions with predefined answer options, one question with an open answer option was also used. This enables the respondents to elaborate on the answer and to name aspects that were not considered during the construction of the questionnaire [13]. The questionnaire was created online and the link was sent to the CSA e-mail distributor interviewed. The results were automatically summarized, statistically evaluated [14] and graphically presented for illustration. The questions relate to a possible sustainable basic attitude of the members, the motives of their membership, their social commitment and the perceived personal added value through the concept of the CSA. In addition to the studies examined, the question of how a membership affects the further consumer behavior of the members was also investigated.

The interview with the founder took place on 23rd November 2018. The chosen form of the interview is called an expert interview, which means that the interviewee is understood as an expert with appropriate specialist knowledge brunner2015leitfaden. An open and case-related de- 
sign serves to describe human action in cultural orientations. Specialist narratives from practical experience and well-founded experiences are explained in detail. The research interest focuses on the concept of the surveyed CSA. In this guideline-supported individual case study, the motivation of the farmer was asked, as well as the personal perception of changed framework conditions and consumer trends in everyday business. In order to shed light on the farmer's financial situation, questions on support measures for innovations and competition measures introduced to maintain margins are integrated into the discussion guide $[14,15]$. The results of this qualitative data collection serve to compare the further development of theoretical hypotheses. More general and abstract relationships are specified [14].

\section{LITERATURE REVIEW}

\section{A. Sustainability Economics}

The sustainability movement aims to combine wealth creation, environmental protection and social cooperation and to satisfy the basic needs of the population on a sustainable basis. The aim is to achieve sustainable and resilient growth. General conditions such as the strongly varying climate, the increasing water shortage and the population growth to 8,949 million people by the year 2050 complicate the desired sustainability movement [2]. Due to climate change, water temperatures are expected to rise, increasing the risk of flooding and further increasing water scarcity. According to a study by the Intergovernmental Panel on Climate Change (IPCC) 2014, the percentage increase in surfaces under water scarcity will increase from the current 19 Percent to 35 Percent by 2070 . With a forecast temperature increase of five degree Celsius by 2080, prolonged periods of drought, especially in southern Europe, will become increasingly apparent [16].

A central goal of the sustainability movement is the sustainable satisfaction of basic needs and thus food security for society [2]. The agricultural economy is of central importance in terms of sustainably securing the basic need for food supply [1]. This leads to the existential goal of developing the food system into a sustainable food system. Soil, water and climate conditions must be sustainably improved [17], because clean water, nutritious soil and a suitable climate are among the basic prerequisites for the production of food [1]. Since the agricultural sector correlates with these aspects, basic measures and practices for the sustainable satisfaction of basic needs must be defined and developed [18].

The food system must become more resilient in order to meet future challenges and megatrends [17]. To this end, regional adaptation plans must be developed and monitoring activities to raise awareness of the early warning system, which should predict the time of a possible catastrophe and its impact, intensified. With regard to the changed availability of water, innovations for more efficient water use and water reuse could positively support development. As countermeasures to floods and droughts, measures such as the restoration of wetlands, the improvement of flood zone management and the introduction of flood and drought insurance could improve the critical situation. Sufficient seed variation can also have positive effects on water, air and soil [1]. The preservation of ecological corridors, e.g. through fallow and compensation areas for wild plants and animals, or a general expansion of plant diversity would be possible countermeasures to the prevailing decline in biodiversity [16].

\section{B. Agricultural Economics}

In addition to the lasting consequences of climate change, changing framework conditions in the food industry shape the day-to-day business of farmers, traders and manufacturers. They increasingly have to deal with changing consumer trends, stricter environmental and nutrition regulations, as well as policy reforms Common Agricultural Policy 2003 and the consequences of globalization [12].

The critical environmental conditions of climate change are giving rise to consumer trends, such as rising concerns about food security. The local cultivation of food as well as the local reference of seeds are increasingly gaining recognition. However, the new environmental and safety regulations vary greatly around the world and lead to growing competitive pressure in the food industry in the context of market globalization. In order to withstand this increasing competitive pressure, many companies have to enter into cooperation and strategic agreements. This enables a company to secure its market share and increases margins through increased negotiating power [12]. Analyses have shown that imports and exports of intermediate products between countries in particular make an important contribution to stabilizing developments in the German food sector. In 2007, this amounted to 4.5 trillion euros [19]. However, due to the small scale of agricultural business, many farmers see themselves in a weak trading position in relation to industrial and large-scale distributors [12].

Due to the weak bargaining position of smaller farmers, productivity is declining and yield pressure is increasing. The economic goal of productivity depends on good environmental conditions such as a fertile crop. Due to the current deterioration of agricultural conditions, farmers are depen- 
dent on climate-conscious expansion. Such investments are not financially viable for many smaller farmers. The possibilities to increase yields are limited in many situations, especially in the area of traditional agricultural activities. However, the integration of more environmentally friendly and animal welfare-friendly measures opens up new possibilities, such as financial instrumental support for the Common Agricultural Policy (CAP) [5]. Financial state support can make it possible to implement protective measures for land and soil and thus ensure productivity in the agricultural sector [20]. The assumption that financial services in the agricultural sector are associated with a high risk leads to high interest rates and service costs for farmers. The financially difficult situation is thus increasingly exacerbated [21]. Another indicator of the critical financial situation of the agricultural economy can be derived from the drop in the share of agriculture in Gross Domestic Product (GDP) from 73 Percent in 1810 to one Percent in 2006. In addition, many smaller farms are dominated by the misallocation of production costs and the price of agricultural products. The costs for production and employees rise more strongly than the yields of farmers through the sale of their harvest [5].

\section{Public Welfare Economy}

For biodynamic farmers, the protection of natural and social resources is a priority. They generate profits without maximizing them and thus operate according to an alternative economic model, which is referred to as the public welfare economy [22]. Based on the assumption that economic growth is subject to limits, a reduction in production and consumption is affirmed. Material abundance is to be replaced by a better quality of life with stronger social, local and ecological connections [23]. Due to high-quality products and the resulting price premium, farmers are dependent on equally oriented customers and employees [22]. Alternative Food Networks also act according to this concept. They demand a socially fair price for food and can be found above all in organic, local and fair-trade food. Due to increasing problems in the globalized food system, AFNs have been rapidly gaining popularity worldwide for 30 years, especially the Community Supported Agriculture [24].

The CSA is an alternative marketing and distribution system [25] in which agricultural holdings with private households form an economic community. Small, local farms will thus be able to devote themselves to agricultural practice independently of market constraints. By subscribing to food for a season [26], households share the risk of production [6]. Members also volunteer on the farm [23]. The reliable participation of the members is crucial for building and main- taining a community [27]. However, studies show that only a few members have a sufficient interest in participation. The burden thus falls back on the farmers, who cannot manage sustainably due to excessive demands. As a result, more market-oriented CSAs are forming, which offer membership exclusively against payment of membership fees [26]. For all concepts, the monthly contributions should enable farmers to earn reasonable wages after covering production costs [6]. These costs are estimated by the farmer before each year and disclosed to the members. The amount of the contributions will be determined jointly within this framework. In return, the farmer foregoes any possible profit and offers consumers high-quality food at the lowest possible price [23]. The behavior of producers and consumers is not based on pure self-interest as in the classic microeconomic model of Homo Economicus. In reality, however, this ideal often leads to self-exploitation of farmers [23].

The merits of farmers and their financial motivation were examined in a study [6] which focused on economic rent. These additional profits can be generated from the organic certification and the economic rent of the Community. The latter is made possible by building trust in the quality of the products [6]. Despite these rents, around 50 Percent of farmers are dissatisfied with their remuneration and around 70 Percent with their financial security [6]. The problem is that farmers do not allocate appropriate economic returns when calculating their wages, often on the basis of non-capitalist ideologies. These ideologies include, for example, a sense of personal commitment to people's well-being and the pleasure they take in their work, which they see as a means of countering the consequences of a crisis in the industrial food system [6]. Furthermore, many farmers aim to educate their members about healthier and more sustainable consumption and to bring them closer to solidarity through the development of a community relationship [27]. Without adequate remuneration, the longterm existence of the CSAs cannot be guaranteed, as an increase in profitability through environmental degradation or labor exploitation is ruled out. A study investigating why farmers leave the CSA shows that 34.4 Percent leave because of insufficient income and 12.5 Percent because of burnout. In the longer term, the income of CSA farmers could fall even further as market entry barriers are low and economic rents are subject to competition erosion [6]. Currently, the number of CSAs is increasing due to a growing consumer interest in their food. These include repeated food scandals such as BSE, the colibacterium and bird flu. One study found that the growth of CSAs is the result of confidence-building strategies aimed at prevent- 
ing food crises and the introduction of genetic engineering [24]. The most frequently cited reason for membership is the purchase of frozen, organic food [26]. It has also been shown that especially people who already have a greater interest in and knowledge of a healthy diet and lifestyle decide for membership [25]. Another reason often cited is support for local farmers. Less often, reasons have been given that people want to be connected to their food source or have a particular interest in agricultural and environmental issues. A study that specifically addresses the ethical reasons of members shows that most members of the CSA already had a greater environmental awareness before their membership, which is further increased by membership [26]. A further study among 1300 volunteers shows that the social commitment to voluntary work and various political activities for the community is greater among CSA members than among the general population [28]. Members who are also actively involved in the harvest feel more emotionally connected to the CSA. The emotional value relates mainly to the support of the farmers and the fulfilment of civic responsibility. Furthermore, the members perceive the cooperation as happiness; stress reduction and a sense of achievement [29].

\section{EMPIRICAL RESULTS}

\section{A. Framework of the Empirical Method}

The aim of the project was to examine the changed conditions for farmers with regard to the environment, consumers and state regulation. For this reason, an expert interview with the founder of surveyed CSA was chosen as the methodology for the student research project. Furthermore, an online survey was conducted among 46 of the 82 members of the association in order to compare the motives of the members with those of the literature sources. In addition, the effects of participation in a CSA on consumer attitudes towards consumer behavior was examined.

\section{B. Sustainability Economics}

The organic trend of the sustainability movement began in 1924 with the "Demeter" organic farming association and expanded in 1970 with the "BIOLAND" organic farming association. The members of such associations were free in the design of the guidelines and imposed the rules themselves. An ethical and sustainable basic attitude to the concept of organic agriculture and a sustainable awareness of society with regard to environmental protection emerged. Despite various countermeasures, the changes caused by environmental pollution have been clearly noticeable again since 2002. The regularity and variety of weather condi- tions within the typical four seasons "(...) have long ceased to exist". After the strong dry period from 2003 to 2005, a more intensive weather situation could be determined again since 2012. A clear lack of water was one of the consequences. Since March 2018 there was November 2018 "(...) actually no more rainfall (...)", which represents one of the fundamental success factors of agriculture. The rainfall was limited to only a few and compressed five liters per square meter, which the soil could not absorb comprehensively. Short-term, compressed precipitation and climate change make erosion damage and pest infestation in agriculture a constantly growing challenge. In order to restore the balance in the environment, investments, for example in irrigation, are becoming increasingly important. In addition to investments in water supply systems, investments are also required due to ever-new environmental regulations.

\section{Agricultural Economics}

In most cases, environmentally friendly measures and the resulting necessary investments are only supported by the state depending on the economic profitability of a company. A five-hectare farm, such as the surveyed CSA, is a small farm that cannot be sufficiently economically justified and therefore receives no instrumental support from government organizations such as the CAP, a policy area of the European Union. There is also a decreasing trend in the financial share of the EU budget for the CAP. In addition to such financial trend changes, consumer trends are also contributing to changes in farmers' framework conditions. A few years ago, the consumer trend concentrated on organic food. Today, there has been a clear shift in the focus of food consumption towards the local aspect. This new attitude on the part of consumers is leading to further competition for farmers. The government's decision to make organic products available to all social classes led to the establishment of many alternative organic labels from 1995 onwards. These are so-called "low-budget" organic labels which do not include sustainability costs and can therefore offer organic products at a lower price. These products meet the minimum requirements and pursue no ethnic, but only economic aspects. Since the difference between the organic labels is not perceived by most customers, most customers decide for the cheaper "low-budget" product. The bio-dynamic and thus more expensive product, such as that of the surveyed CSA, can only with difficulty oppose the consumer's decision. There is price competition. Additional pressure for farmers was created by the introduction of the minimum wage in the agricultural sector and the simultane- 
ous trend towards ever cheaper food supplies. While costs are rising due to the wage increase, yields are falling due to the growing price pressure of competitors with regard to sales prices.

In order to withstand the emerging economic pressures, many smaller farms feel compelled to contradict the principles of biodynamic cultivation and exploit either the soil or man. The surveyed CSA alternatively concentrates on the cultivation of several crops and distribution to resellers, as this is a better and more sustainable response to competitive pressure for the farmer. This concept is currently being supplemented by cooperation with other biodynamic farms in the region in order to be able to offer customers a broader and therefore more attractive range of products from a single source.

\section{Public Welfare Economics}

Due to the difficult financial situation, the CSA is the only way to maintain surveyed CSA's biodynamic cultivation without expanding. The farmer's motivation is to "work with people [...] instead of farming large fields with modern tractors". The CSA offers a further financial pillar to cover the running costs of the farm. Since the surveyed CSA does not yet have enough members to exist exclusively as a CSA, 70 Percent of its funding comes from sales to resellers. Thus, the company already succeeds in alleviating the price pressure of the wholesale trade and guaranteeing the costs for fair wages and the preservation of soil quality. Furthermore, the CSA is the result of ethical motives. The farmer sees it as his task to sensitize as many people as possible to agricultural and ecological issues. Conversely, this means that more people are prepared to bear the actual costs of food. Working with other people is one of CSA's top priorities, but it is also the biggest challenge. For the gardener, social competence is a basic building block of the business. Members must be won over and motivated. The opinions of the members are on an equal footing with those of the gardener, which requires complex member management. In addition, there is the relevance of knowledge about a broad spectrum of plants and their requirements, since the specialized cultivation of monocultures and biodynamic cultivation are mutually exclusive. All in all, the gardener does pioneering work with the CSA and is thus constantly confronted with new challenges. These, however, are profitable, so that the goal of the gardener is to increase the number of members from the current 82 (November 2018) to 300 . This would enable a complete conversion to the CSA. Although agriculture within organic associations is often associated with a certain degree of self-exploitation due to ethical and non-economic motives, this can be avoided by a thorough calculation of costs.

The results of the survey among members regarding motivation to join reflect the results of previous studies. Members cite food quality as the primary reason, followed by environmental reasons, followed by financial support for regional farmers. Less strongly represented is the interest in agricultural and environmental topics, as well as the need to find a balance to working life by working on the farm (Figure 1).

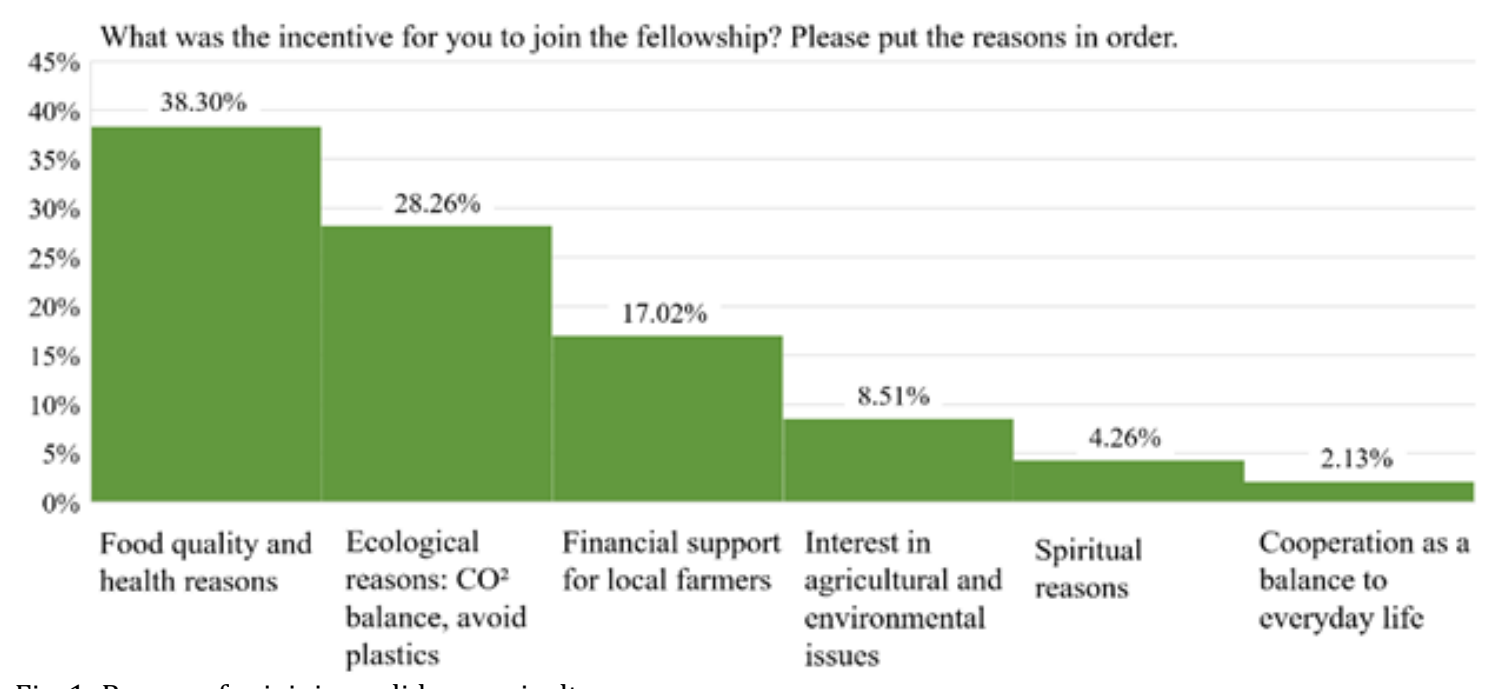

Fig. 1. Reasons for joining solidary agriculture

This result also explains the already known problem of insufficient support from members. Only 35 Percent of the members take part in the volunteer days, although almost 90 Percent say they feel emotionally connected to solidarity agriculture (Figure 2). However, the assumption that there is a statistically significant connection between the feeling of emotional solidarity and the stronger commitment, as shown by other studies, cannot be substantiated. 
Binary Questions

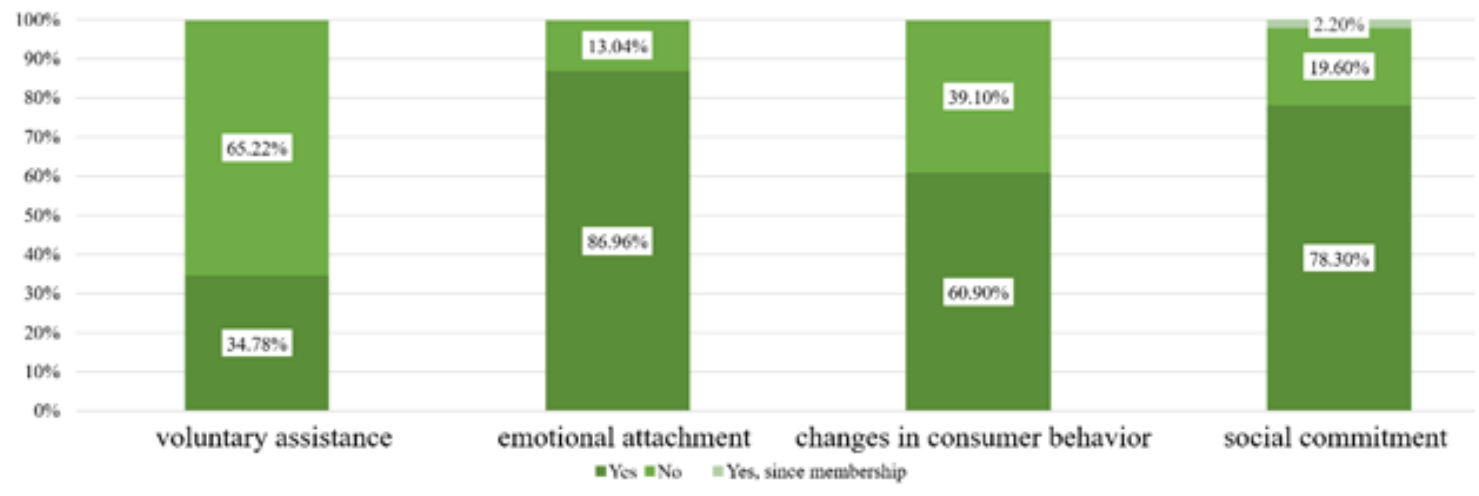

Fig. 2. Binary questions

Nearly 50 Percent of those who indicated that they participated in the voluntary helper days indicated that the value of knowledge was the greatest added value for them. This is defined as "awakens curiosity; expands knowledge". Furthermore, the social value plays a major role, which is defined as "Extends the social circle; promotes friendships".
The emotional value, which means "happiness; stress reduction; feeling of having achieved something", is most often given as the second most important value. The health value, which means "work in the fresh air; exercise", is most often given as the third value (Figure 3).

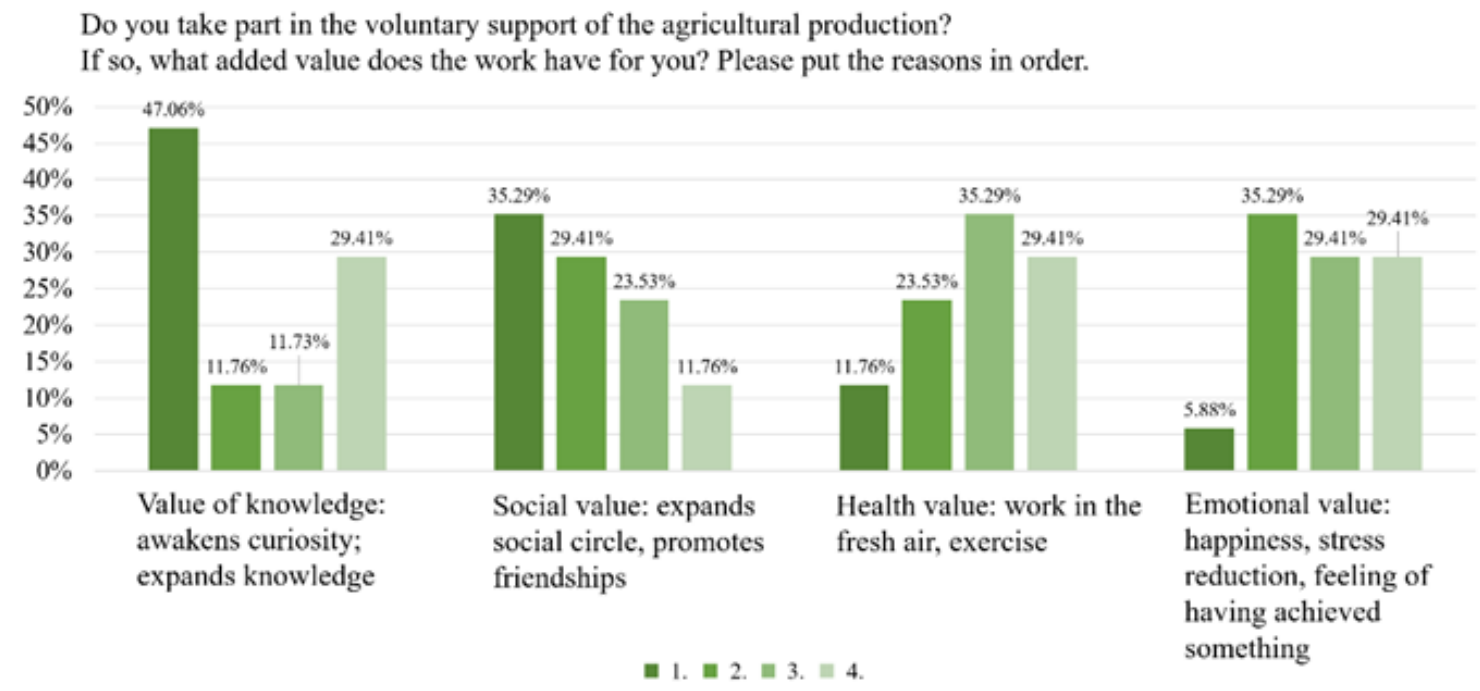

Fig. 3. Added value of voluntary support

Another aim of this study was to find out whether the consumer behavior of members has changed as a result of membership. For this purpose, the purchasing behavior before membership was surveyed. More than 70 Percent of the respondents stated that they felt it was important or very important to shop organically and locally even before becoming a member (Figure 4).

This result is a reflection of previous research, which has shown that CSA members were more environmentally aware before their membership, but that their relationship to food continued to grow. Nearly 40 Percent of surveyed CSA members also report that their consumption patterns have continued to change since their member-ship (Figure 3). However, there is no statistically significant correlation between those who were already paying attention to local and organic products before their membership and those whose consumption behavior has changed since membership. In addition to the statement that they also pay attention to organic and local cultivation when shopping for other foods, the interviewees state that they are increasingly questioning their consumption in general and the associated cause of garbage, and that they are buying second hand more frequently. 
How would you describe your purchasing behavior before becoming a member? Multiple answers possible.

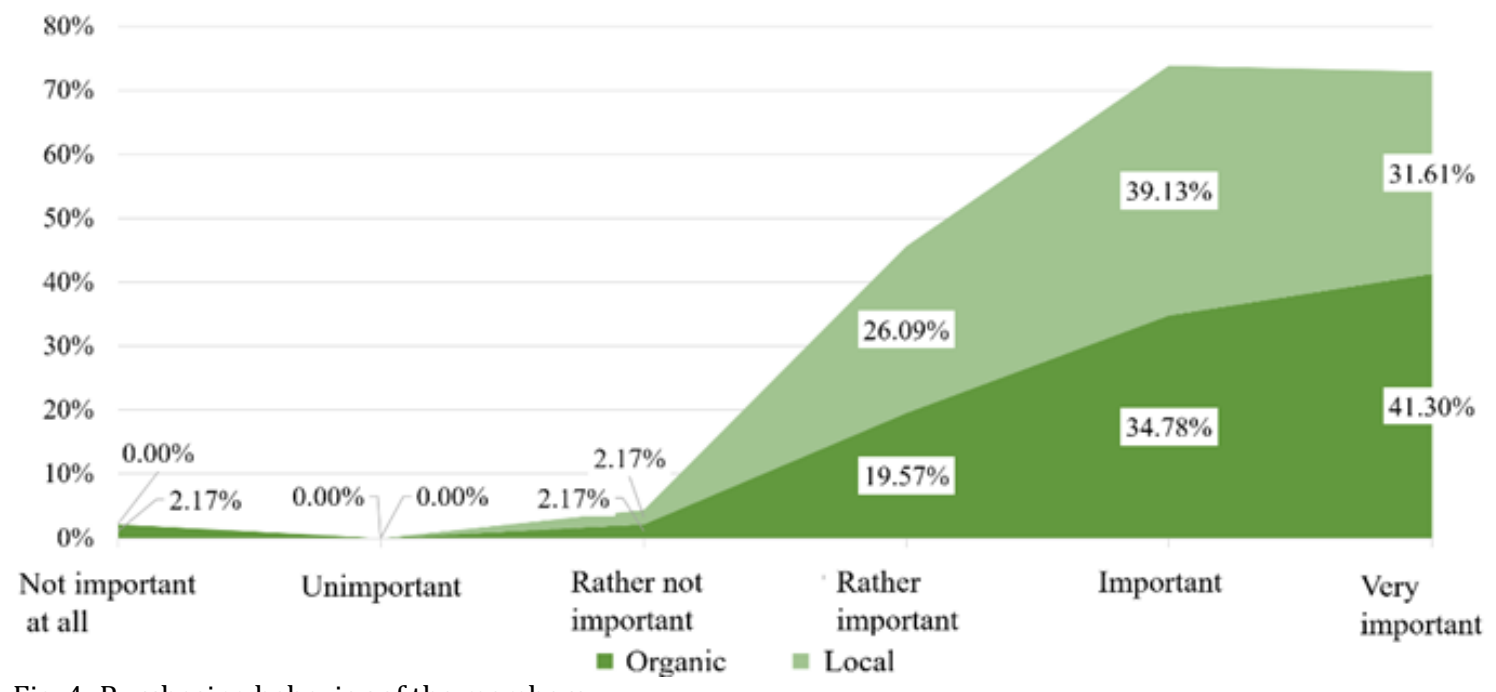

Fig. 4. Purchasing behavior of the members

\section{CONCLUSION AND RESEARCH OUTLOOK}

\section{A. Summary}

The rising costs [12] resulting from the limited availability of natural resources [1] and the growing demand for more sustainability in society [2], represents a dilemma for agriculture as a means of food security [12]. This paper examines whether the concept of the CSA can provide a solution to the dilemma. The methodological approach includes a theoretical and empirical investigation. By means of an expert interview it is shown whether the con-cept of the CSA is economically viable, by an online survey of the members the social views are represented. The study of existing literature shows that in order to sustainably secure a functioning food system, the factors soil, water and climate must be improved by supporting measures in order to achieve the goal of satisfying the basic need for food [1]. Due to the associated innovation constraints in the agricultural sector as well as legal and social changes [12], farmers find themselves in a financial dilemma [5]. Through alternative concepts such as the CSA, farmers can act more independently of market constraints, devote themselves to agricultural practice [26] and thereby maintain sustainable food production [23]. The difficult environmental and economic conditions, as well as the CSA as a possible solution to the farmers' prob-lem, are confirmed in the empirical study. The well-known problem of self-exploitation of farmers in the CSA is also confirmed but does not pose a problem for the CSA. On the part of the members, a great interest in the concept of the CSA as well as a change of consciousness towards more sustainability can be observed.

\section{B. Discussion and conclusion}

The present study uses an expert interview to examine whether the concept of the CSA represents a solution to the dilemma of agriculture. One limitation of the work is that only one expert was interviewed. Within the scope of an intensive literature research, however, a comprehensive picture of the changed framework conditions in agriculture could be created, which was meaningfully supplemented by the survey of the expert in surveyed CSA. The second limit of this work lies in the small sample size of the survey among the members of the sur-veyed CSA. No conclusion can be drawn as to whether the result is generally valid. However, the aim of this work is to systematically analyze the value changes and sustainable development of the members of the sur-veyed CSA and to be able to compare the results with those of the literature. The sample size corresponds to 57 Percent of the members, so it can be assumed that the result reflects the opinion of the members in the surveyed CSA. The third limit of this work lies in the fact that the survey was carried out exclusively among members of the CSA, which lacks a comparison with the general population. This makes it impossible to make any connec-tions between, for example, the price pressure for agricultural products in trade and the current income situation of society. A further aim of this work, however, is to be able to make a recommendation for action to win new members. For this, it is sufficient to record and evaluate the reasons of the current members.

\section{Outlook}

The work deals with the implemented concept of the surveyed CSA and examines positive and negative motivators 
and driving forces. Further, the origin of the coercion to alternative food systems could be investigated in order to derive necessary measures to reduce the origin problem. The questions shown in Table 2 remain open.

The aim of the surveyed CSA farmer is to increase the number of members from the current 82 to 300 . To achieve this, it is necessary to actively recruit new members. The work shows that 40 Percent of the members of the surveyed CSA are members because of the quality of the food and 30 Percent for ecological reasons, such as the avoidance of plastic. Since these motives are also relevant to other potential customers, these factors should be actively promoted. Furthermore, it could be shown that the majority of the members were already interested in local and organic foods before their membership and that 78 Percent were socially com- mitted before their membership. Thus, a conclusion can be drawn, where new members could be found. Addressing potential customers at weekly markets, near organic food markets and in front of social institutions is potentially promising. It was also shown that 87 Percent of members feel emotionally attached to the surveyed CSA, but only 35 Percent actively support the volunteer days. However, it can be assumed that the workload for the care of 300 members will increase sharply and cannot be handled by the current workforce. An increase of the monthly contribution for noncooperating members should be considered in order to be able to employ new workers. Due to the emotional commitment of the members, it can be assumed that this increase will be accepted.

TABLE 2

OPEN RESEARCH QUESTIONS

\begin{tabular}{lll}
\hline \hline Scientific Field & No. & Open Research Questions \\
\hline Sustainability economics & 1 & How does competition influence the development of sustainability? \\
& 2 & How can the sustainability movement be strengthened? \\
& 3 & In which areas are sustainable measures lacking? \\
Agricultural economics & 4 & Are there ways to offer sustainable organic products at a lower price? \\
& 5 & How can costs in agricultural productions be reduced? \\
& 6 & Is it still possible to supply food without imports? \\
Public welfare economics & 7 & Which alternative concepts do exist? \\
& 8 & Is the CSA a general solution to the agricultural dilemma? \\
& 9 & How can the misallocation of revenues and costs be counteracted by the state? \\
\hline \hline
\end{tabular}

\section{REFERENCES}

[1] R. Magda, "Economic questions of land usage scarcity, sustainability," Applied Studies in Agribusiness and Commerce, vol. 6, no. 1, pp. 43-48, 2012.

[2] E. L. Molua, J. K. Benhin, J. Kabubo-Mariara, M. Ouedraogo, and S. El-Marsafawy, "Global climate change and vulnerability of African agriculture: Implications for resilience and sustained productive capacity," Quarterly Journal of International Agriculture, vol. 49, no. 4, pp. 183-211, 2010. doi: https://doi.org/10.22004/ag.econ.155547

[3] M. Št'astná, F. To man, and J. Dufková, "How to improve landscape sustainability?" Problems of World Agriculture/Problemy Rolnictwa Światowego, vol. 1, no. 1827-2016-147602, pp. 80-87, 2007. doi: https://doi.org/10.22004/ag.econ. 198957

[4] B. M. Campbell, J. Hansen, J. Rioux, C. M. Stirling, S. Twomlow et al., "Urgent action to combat climate change and its impacts (SDG 13): Transforming agriculture and food systems," Current Opinion in Environmental Sustainability, vol. 34, pp. 13-20, 2018. doi: https://doi.org/10.1016/j.cosust.2018.06.005

[5] H. Runowski and W. Zietara, "Future role of agriculture in multifunctional development of rural areas," Applied Studies in Agribusiness and Commerce, vol. 4, no. 5-6, pp. 135-143, 2010. doi: https://doi.org/10.19041/APSTRACT/2010/ $5-6 / 22$

[6] R. E. Galt, "The moral economy is a double-edged sword: Explaining farmers' earnings and self-exploitation in community-supported agriculture," Economic Geography, vol. 89, no. 4, pp. 341-365, 2013.

[7] B. Sandberg, Wissenschaftliches Arbeiten von Abbildung bis Zitat: Lehr-und Übungsbuch für Bachelor, Master und Promotion. London, UK: Walter de Gruyter GmbH \& Co KG, 2016. 
[8] W. Wanja, L. Daniela, and R. Linda, "Importance of automobile interior for sustainability in the automotive industry: The case of volume manufacturers," Journal of Applied and Physical Sciences, vol. 4, no. 2, pp. 60-68, 2018. doi: https: //doi.org/10.20474/japs-4.2.3

[9] M. D. Teli, S. P. Valia, S. Maurya, and P. Shitole, "Sustainability based upcycling and value addition of textile apparels," International Journal of Applied and Physical Sciences, vol. 1, no. 3, pp. 55-60, 2015. doi: https://doi.org/10.20469/ ijaps.50002-3

[10] U. Kipman, T. Reiter, and U. Leopold-Wildburger, Wissenschaftliches Arbeiten 4.0. Berlin, Germany: Springer, 2018.

[11] P. Atteslander, Methoden der Empirischen Sozialforschung. Berlin, Germany: Auflage, 2006.

[12] C. Fischer, M. Hartmann, M. Bavorova, H. Hockmann, H. Suvanto, L. Viitaharju, P. Leat, C. Revoredo-Giha, M. Henchion, C. McGee et al., "Business relationships and B2B communication in selected European agri-food chains-first empirical evidence," International Food and Agribusiness Management Association, vol. 11, no. 2, pp. 73-100, 2008.

[13] S. Hollenberg, Fragebogen. Wiesbaden, Germany: Springer Verlag, 2016.

[14] H. Brunner, D. Knitel, P. J. Resinger, and R. Mader, Leitfaden zur Bachelor-und Masterarbeit: Einführung in Wissenschaftliches Arbeiten und Berufsfeldbezogenes Forschen an Hochschulen und Universitäten. Berlin, Germany: Tectum Wissenschaftsverlag, 2015.

[15] R. Hitzler, A. Honer, and C. Maeder, Die institutionalisierte Kompetenz zur Konstruktion von Wirklichkeit. Berlin, Germany: Springer, 1994.

[16] A. Iglesias and L. Garrote, "Adaptation strategies for agricultural water management under climate change in Europe," Agricultural Water Management, vol. 155, pp. 113-124, 2015. doi: https://doi.org/10.1016/j.agwat.2015.03.014

[17] C. Béné, P. Oosterveer, L. Lamotte, I. D. Brouwer, S. de Haan, S. D. Prager, E. F. Talsma, and C. K. Khoury, "When food systems meet sustainability current narratives and implications for actions,' 'World Development, vol. 113, pp. 116-130, 2019. doi: https://doi.org/10.1016/j.worlddev.2018.08.011

[18] A. Dinar, "Theme overview: Water scarcity, food production, and environmental sustainability-can policy make sense?" Choices, vol. 31, no. 1, pp. 1-34, 2016.

[19] K. A. Mrowczynska, The Significance of Imports in the Supply of Material for Food Economy in Poland and Germany. London, UK: Sage Publications, 2012.

[20] K. D. Wiebe, "Linking land quality, agricultural productivity, and food security," Agricultural Economic Journal, vol. 5, no. 8, pp. 823-840, 2003.

[21] P. Drechsel and B. Keraita, Irrigated Urban Vegetable Production in Ghana: Characteristics, Benefits and Risk Mitigation. London, UK: IWMI, 2014.

[22] W. Sachs, "Suffizienz. umrisse einer ökonomie des genug," Uwf Umwelt Wirtschafts Forum, vol. 23, no. 1-2, pp. 3-9, 2015. doi: https://doi.org/10.1007/s00550-015-0350-y

[23] M. Bloemmen, R. Bobulescu, N. T. Le, and C. Vitari, "Microeconomic degrowth: The case of community supported agriculture," Ecological Economics, vol. 112, no. 7, pp.110-115, 2015. doi: https://doi.org/10.1016/j.ecolecon.2015.02.013

[24] D. Maye and J. Kirwan, "Alternative food networks," Sociology of Agriculture and Food, vol. 20, no. 3, pp. 383-389, 2010.

[25] A. Vasquez, N. E. Sherwood, N. Larson, and M. Story, "Community-supported agriculture as a dietary and health improvement strategy: A narrative review," Journal of the Academy of Nutrition and Dietetics, vol. 117, no. 4, pp. 83-94, 2017.

[26] J. Hayden and D. Buck, "Doing community supported agriculture: Tactile space, affect and effects of membership," Geoforum, vol. 43, no. 2, pp. 332-341, 2012. doi: https://doi.org/10.1016/j.geoforum.2011.08.003

[27] B. Balázs, G. Pataki, and O. Lazányi, "Prospects for the future: Community supported agriculture in Hungary," Futures, vol. 83, no. 6, pp. 100-111, 2016. doi: https://doi.org/10.1016/j.futures.2016.03.005

[28] B. K. Obach and K. Tobin, "Civic agriculture and community engagement," Agriculture and Human Values, vol. 31, no. 2, pp. 307-322, 2014. doi: https://doi.org/10.1007/s10460-013-9477-z

[29] W. Chen, "Perceived value of a Community Supported Agriculture (CSA) working share: The construct and its dimensions," Appetite, vol. 62, pp. 37-49, 2013. doi: https://doi.org/10.1016/j.appet.2012.11.014 